\title{
INOVASI SUSU ALMOND DENGAN SUBSTITUSI SARI KECAMBAH KEDELAI SEBAGAI SUMBER PROTEIN NABATI
}

\section{The Innovation of Soybean Sprouts-Substituted Almond Milk as the Source of Vegetable Protein}

\author{
Sarah Sri Damayanti*, Erni Sofia Murtini \\ Jurusan Teknologi Hasil Pertanian, FTP Universitas Brawijaya Malang \\ JI.Veteran, Malang 65145 \\ *Penulis korespondensi, Email: sarahdamayanti17@gmail.com
}

\begin{abstract}
ABSTRAK
Produk olahan almond kini semakin bervariasi, bukan hanya untuk produk makanan melainkan juga minuman. Salah satu minuman berbasis almond yang mulai diminati adalah susu almond. Namun, kadar protein larut air yang rendah pada susu almond tidak memenuhi standar SNI , maka susu almond harus ditambahkan sumber protein dari luar, seperti kedelai. Penelitian menggunakan Rancangan Acak Kelompok (RAK) faktorial. Faktor I adalah teknik blanching almond (water blanching dan steam blanching). Faktor II adalah lama waktu perkecambahan kedelai (12 jam, 20 jam, 28 jam, dan 36 jam). Perlakuan terbaik didapatkan pada perlakuan steam blanching almond dan perkecambahan kedelai 36 jam. Hasil analisis perlakuan terbaik produk mempunyai kadar air sebanyak $81.15 \%$, kadar protein $15.01 \%$, kadar lemak $1.99 \%$, karbohidrat by difference $1.11 \%$, kadar abu $0.75 \%$, dan natrium 87.72 ppm.
\end{abstract}

Kata Kunci : Asam Fitat, Blanching, Lama Perkecambahan, Protein Larut Air, Tanin

\section{ABSTRACT}

Processed almond products are now more varied, not only for food products but also beverages. One of the rising processed products of Almond was Almond Milk. However, the content of protein solved in water was less than the standard of Nationalized Standard of Product or so called as SNI. Therefore, it was necessary to give additional protein from other substances, such as soybean. This study implements factorial Randomized Grouping Design (RGD). Factor I was the blanching technique of almond (water blanching an steam blanching). Factor II was the period of soybean germination (12 hours, 20 hours, 28 hours, an 36 hours). The best treatment obtained from steam blanching of almond and soybean germination for 36 hours. The best treatment of the product contains $81.15 \%$ of water, $15.01 \%$ of protein, $1.99 \%$ of fat, $1.11 \%$ of by difference-carbohydrate, $0.75 \%$ of ash, and $87.72 \mathrm{ppm}$ of natrium.

Keywords: Blanching, Long Germination, Phytic Acid, Soluble Protein, Tannin

\section{PENDAHULUAN}

Almond merupakan jenis tree nuts yang populer karena rasanya yang gurih, sedikit manis, dan empuk. Cita rasa gurih pada almond dikarenakan tingginya lemak nabati yang terkandung di dalamnya. Almond mengandung tinggi nutrisi, per 100 gram total lemak (nabati) sebesar $49.9 \mathrm{~g}$, serat pangan $12.2 \mathrm{~g}$, vitamin B (B1, B2, B3, B6) $4.7 \mathrm{mg}$, vitamin E $25.63 \mathrm{mg}$, serta tinggi $\mathrm{Ca}$, $\mathrm{K}$, dan $\mathrm{P}$ masing masing 269.481, dan 733 mg (USDA, 2016). Konsumsi satu takaran saji almond (20-25 biji) akan menghasilkan 15 gram lemak, dan lebih dari 90 persennya merupakan asam lemak tidak jenuh (Victoria, 2008). Tingginya asam oleat dan linoleat pada almond sangat berperan baik dalam tubuh salah satunya menekan kolesterol sehingga baik untuk jantung serta meningkatkan laju aliran darah. 
Almond memang produk impor dan mahal, akan tetapi rasa gurih yang tak tergantikan ditambah dengan kandungan gizinya yang tinggi membuat almond selalu banyak peminat. Salah satu olahan almond yang mulai menjadi trend adalah susu almond. Terbukti bahwa di Amerika jumlah penjualan susu almond terus meningkat hingga $250 \%$ pada 5 tahun terakhir dan menduduki posisi teratas dibandingkan dengan susu dari kacang-kacangan dan serealia lain (Nielsen, 2016). Susu almond juga dapat digunakan sebagai alternatif susu sapi bagi penderita lactose intolerace mengingat di Indonesia, prevalensi penderita lactose intolerance berdasarkan penelitian yang dilakukan di Jakarta, sebesar $57.9 \%$ pada anak usia 6-7 tahun, 58.9\% pada anak usia 8-9 tahun, dan 57.1\% pada anak 10-12 tahun (Purwati et al., 2015).

Dibalik kelezatannya, susu almond memiliki beberapa kekurangan yakni bahan baku almond mengandung asam fitat yang tinggi dan mengandung sangat sedikit protein larut air yakni sekitar $0.42 \mathrm{~g} / 100 \mathrm{~g}$ (USDA, 2016). Menurut SNI No. 01-3830-1995, susu dari komoditas nabati harus memiliki protein minimal $2 \%$ dan dalam bentuk minuman minimal $1 \%$ sehingga untuk meningkatkan kadar proteinnya perlu ditambahkan protein dari luar atau dari komoditas lain. Kedelai dikenal sebagai salah satu kacang-kacangan yang tinggi protein nabati sekitar $35.71 \%$ (USDA, 2016) sehingga dapat digunakan sebagai komoditas untuk substitusi susu almond. Penelitian terdahulu mengenai susu almond yang disubstitusi dengan komoditas lain telah dilakukan oleh (Nareswara, 2016) yang mejadikan kentang sebagai bahan substitusi susu almond bagi anak-anak penderita Autism Spectrum Disorder (ASD) sebagai minuman bebas kasein dan gluten serta ppeningkatan gizi lainnya untuk perkembangan penderita ASD.

Susu almond dengan substitusi kedelai dapat dibuat dengan proporsi almond:kedelai sebanyak 2:1 (Potter, 2016). Pemilihan kacang kedelai sebagai sumber protein nabati pada susu almond selain dari segi kadar proteinnya juga dipertimbangkan dari nilai ekonomis sebagai pengimbang harga almond yang mahal. Selain itu, pasokan kedelai juga mudah didapatkan di pasaran. Namun, susu almond dengan substitusi sari kecambah kedelai memiliki permasalahan yaitu kadar zat anti gizi asam fitat dan tanin yang tinggi. Asam fitat mampu mengikat beberapa mineral dan tanin mampu mengikat protein sehingga kebutuhan tubuh akan mineral dan protein akan terganggu penyerapannya.

Menurut penelitian Mardiyanto dan Sri (2015), asam fitat dan tanin, dapat diturunkan dengan perlakuan pendahuan berupa perkecambahan. Sedangkan menurut penelitian Pramita (2008) penurunan kadar zat antigizi dapat dilakukan dengan bantuan pemanasan. Salah satu perlakuan panas pada pengolahan bahan pangan adalah blanching yang mempunyai dua teknik yakni water blanching dan steam blanching. Kombinasi perlakuan yang paling efektif antara waktu perkecambahan dan teknik blanching diharapakan mampu menaikkan kadar protein larut air serta menurunkan kadar asam fitat dan tanin juga menambah nilai gizi dari susu almond substitusi sari kecambah kedelai terutama protein.

\section{BAHAN DAN METODE}

\section{Alat}

Alat untuk pembuatan antara lain blender maspion, plate alumunium untuk pasteurisasi dan water blanching, panci penanak nasi untuk steam blanching, kain saring. Untuk analisis digunakan spektrofotometer UV-Vis 20D plus (Bausch and Lo,mb, USA), AAS AA6300 (Shimadzu, California), sentrifuge EBA 2000 (Hettich Zentrifugen, Belanda), vortex (LW Scientific Inc, USA), shaker (Heidolph UN, Germany) Furnace 47900 (Thermolyne, USA), seperangkat alat destilasi Genhardt, Indonesia) oven (WTC Binder, Germany), timbangan analitik (Denver Instrument M310, USA) vacuum drying merek lokal, tabung Kjeldahl, lemari asam, magnetik stirer, kompor listrik Maspion.

\section{Bahan}

Bahan pembuatan produk antara lain almond manis, kedelai kering, perisa vanila cair untuk makanan. Sedangkan bahan untuk keperluan analisis (Sigma dan Merck) antara lain $\mathrm{HNO}_{3}$ 0,5 M (PA), $\mathrm{FeCl}_{3}$ 0,5 M (PA), amil alkohol (PA), amonium thiosianat (PA), metanol (PA), $\mathrm{Na}_{2} \mathrm{CO}_{3} 20 \%$ (PA), reagen follin ciocealteau (PA), asam tanat standar (PA), TCA (PA), dietil eter (PA), $\mathrm{K}$ Na Tartrat (PA), $\mathrm{CuSO}_{4} .5 \mathrm{H}_{2} \mathrm{O}$ (PA), $\mathrm{NaOH}$ padat (PA), $\mathrm{NaOH} 30 \%$ (teknis), 
indikator metil red, indikator pp, tablet kjeldahl, $\mathrm{H}_{2} \mathrm{SO}_{4}$ pekat (PA), $\mathrm{H}_{2} \mathrm{SO}_{4} \quad 0,5 \mathrm{~N}(\mathrm{PA})$, petroleum eter (PA), $\mathrm{HNO}_{3}(\mathrm{PA})$ serta akuades.

\section{Metode Penelitian}

Penelitian menggunakan Rancangan Acak Kelompok (RAK) faktorial. Faktor I adalah teknik blanching almond (water blanching dan steam blanching). Faktor II adalah lama waktu perkecambahan kedelai (12 jam, 20 jam, 28 jam, dan 36 jam). Sampel didapatkan 8 kombinasi perlakuan yang akan diulang sebanyak 3 kali sehingga didapatkan sampel uji sebanyak 24 .

\section{Pembuatan Produk}

Pembuatan produk dimulai dari proses pembuatan susu almond dimana almond dilakukan blanching (water dan steam blanching) pada suhu $80^{\circ} \mathrm{C}$ selama 20 menit kemudian dihaluskan dengan menggunakan blender dan ditambah air dengan perbandingan 1:4 lalu disaring dan diperas dengan kain saring. Untuk pembuatan sari kecambah kedelai dilakukan perkecambahan kedelai $(12,20,28$, dan 36 jam) kemudian dihaluskan dengan menggunakan blender dan ditambah air dengan perbandingan 1:1 lalu disaring dan diperas dengan kain saring. Pembuatan produk susu almond substitusi sari kecambah kedelai dilakukan dengan mencampurkan susu almond dan sari kecambah kedelai $(2: 1)$ lalu dipasteurisasi suhu $70^{\circ} \mathrm{C}$ selama 15 menit, dilakukan heatshock, dan pengemasan.

\section{Analisis Kimia}

Sampel produk susu almond dengan substitusi sari kecambah kedelai kemudian dilakukan analisis zat antigizi berupa kadar asam fitat (Davies dan Reid, 1979), kadar tanin (Subagio, 2003), serta analisis kadar protein larut air dengan metode biuret (AOAC, 1995). Kadar protein larut air yang tertinggi serta kadar asam fitat dan tanin yang sudah memenuhi syarat akan diambil sebagai perlakuan terbaik yang nantinya akan diberi klaim sumber protein. Produk dengan perlakuan terbaik selanjutnya dianalisis proximat berupa kadar air (AOAC, 1990), protein (AOAC 2000), lemak (AOAC, 2005) karbohidrat by difference, kadar abu (AOAC, 1990), serta natrium (AOAC 937.09, 2000) untuk pemenuhan syarat klaim sumber protein (PKBPOM No 13 Tahun 2016) termasuk informasi nilai gizi.

\section{Analisis Statistika}

Data dilakukan analisis sidik ragam dengan ANOVA menggunakan software minitab 16 dilanjutkan dengan DMRT apabila terdapat beda nyata $(\alpha=0.05)$ dan interaksi serta BNT apabila beda nyata $(\alpha=0.05)$ namun tidak terdapat interaksi.

\section{HASIL DAN PEMBAHASAN}

\section{Karakteristik Bahan Baku}

Karakteristik almond manis (Prunus amygdalus var. dulcis) dengan kondisi biji utuh yang masih berkulit ari dan kedelai kuning lokal (Glycine max (L.) Merril) dapat dilihat pada Tabel 1.

Tabel 1. Kandungan Bahan Baku

\begin{tabular}{lcc}
\hline \multicolumn{1}{c}{ Parameter } & Almond & Kedelai \\
\hline Protein $(\%)$ & $22.63 \pm 0.57$ & $30.44 \pm 1.25$ \\
Asam Fitat $(\mathrm{mg} / \mathrm{g})$ & $1.641 \pm 0.13$ & $1.50 \pm 0.02$ \\
Tanin $(\mathrm{mg} \mathrm{EAT} / \mathrm{100g})$ & $75.55 \pm 7.61$ & $506.45 \pm 31.25$ \\
\hline
\end{tabular}

Kadar protein almond yang ditunjukkan pada Tabel 1 adalah $21.15 \%$ dimana jika dibandingkan dengan jenis kacang pohon lainnya, protein yang terkandung dalam almond merupakan yang tertinggi dibanding Brazil nut (14.32\%), cashew (18.22\%), hazelnut $(14.95 \%)$, macademia $(7.91 \%)$, pecan $(9.16 \%)$, pistachio $(20.16 \%)$, walnut $(15.23 \%)$ (Tan, 2011). Jenis protein yang ada pada almond antara lain globulin (74\%), albumin (21\%), dan 
sisanya adalah glutelin dan prolamin. Kadar protein kedelai hasil analisis adalah $30.44 \%$ yang apabila di bandingkan dengan jenis kacang-kacangan lain seperti kacang hijau (23.86\%), kacang merah (23.58\%), dan kacang tanah (6.15\%) protein kedelai merupakan yang tertinggi. Protein yang mendominasi kedelai adalah globulin dan albumin. Protein globulin yang merupakan protein tidak larut air kedelai berkisar $19.25 \mathrm{~g} / 100 \mathrm{~g}$ bahan (Yuwono et al., 2003). Nilai daya cerna protein kedelai yang sudah mengalami proses pemasakan sangat tinggi mencapai $70-80 \%$ sehingga sangat mudah diserap oleh tubuh (Purba, 2012).

Kadar tanin pada almond menurut hasil analisis adalah $75.55 \mathrm{mg}$ ekuivalen asam tanat $/ 100 \mathrm{~g}$. Hasil yang sama dilaporkan pada penelitian Monaghan (2008) dimana kadar tanin pada almond adalah $0.07 \%(70 \mathrm{mg} / 100 \mathrm{~g})$. Kandungan tanin yang ada dalam kedelai adalah $506.45 \mathrm{mg}$ ekuivalen asam tanat/100g. Hasil pengukuran kadar tanin tersebut apabila dibandingkan dengan penelitian Rusydi dan Azrina (2012) hampir mendekati yakni 567 mg ekuivalen asam galat $/ 100 \mathrm{~g}$. Sedangkan untuk kadar asam fitat dari almond dan kedelai adalah $1.641 \mathrm{mg} / \mathrm{g}$ dan $1.50 \mathrm{mg} / \mathrm{g}$. Ketika dalam bentuk garamnya, asam fitat merupakan sumber fosfor yang terdapat pada jaringan tanaman (Kumar et al., 2010). Asam fitat terbentuk selama pematangan biji dan $60-90 \%$ nya merupakan fosfor (Leowus, 2002).

\section{Karakteristik Kimia Susu Almond Substitusi Sari Kecambah Kedelai}

Karakteristik kimia susu almond substitusi sari kecambah kedelai berupa kadar protein larut air, asam fitat dan tanin dapat dilihat pada Tabel 2.

Tabel 2. Karakteristik Kimia Susu Almond Substitusi Sari Kecambah Kedelai

\begin{tabular}{lccc}
\hline${ }^{*}$ Perlakuan & Protein Larut Air $(\%)$ & Asam Fitat $(\mathrm{mg} / \mathrm{ml})$ & Tanin $(\mathrm{mg}$ EAT/100ml) \\
\hline A1B1 & $11.05 \pm 0.07$ & $1.27 \pm 0.07$ & $266.53 \pm 16.59$ \\
A1B2 & $11.89 \pm 0.44$ & $1.15 \pm 0.03$ & $246.38 \pm 19.59$ \\
A1B3 & $12.18 \pm 0.19$ & $0.91 \pm 0.02$ & $221.09 \pm 18.18$ \\
A1B4 & $12.76 \pm 0.22$ & $0.82 \pm 0.01$ & $182.56 \pm 15.15$ \\
A2B1 & $12.31 \pm 0.79$ & $1.39 \pm 0.06$ & $292.17 \pm 11.82$ \\
A2B2 & $12.34 \pm 0.16$ & $1.38 \pm 0.08$ & $277.83 \pm 16.80$ \\
A2B3 & $13.46 \pm 0.27$ & $1.19 \pm 0.06$ & $247.23 \pm 12.94$ \\
A2B4 & $15.01 \pm 0.48$ & $1.07 \pm 0.09$ & $232.47 \pm 13.71$
\end{tabular}

${ }^{\star} \mathrm{A} 1$ = water blanching, $\mathrm{A} 2$ = steam blanching, $\mathrm{B} 1=$ perkecambahan 12 jam, $\mathrm{B} 2=20 \mathrm{jam}, \mathrm{B} 3=28 \mathrm{jam}$, $\mathrm{B} 4=36$ jam

\section{Protein Larut Air}

Pada Tabel 2 hasil analisis statistik menunjukkan perlakuan teknik blanching almond dan lama perkecambahan kedelai berpengaruh nyata $(\alpha=0.05)$ terhadap kenaikan protein larut air serta terdapat interaksi keduanya. Hal ini dikarenakan proses perkecambahan menyebabkan naiknya beberapa komponen nutrisi seperti protein dan vitamin. Meningkatnya kadar protein dikarenakan sintesis protein terjadi setelah kebutuhan energi untuk pertumbuhan telah habis (karbohidrat pada biji). Oleh karena itu, protein digunakan sebagai cadangan makanan yang digunakan untuk membesarkan diri dan untuk proses respirasi selanjutnya pada saat diperlukan untuk berkembang (Suhendra, 2005). Protein larut air pada perlakuan water blanching lebih rendah dibandingkan dengan steam blanching karena protein lebih banyak larut dalam air rebusan (jumlah pelarut lebih banyak) tergantung lama dan suhu blanching (Naibaho et al., 2009).

\section{Asam Fitat}

Pada Tabel 2 hasil analisis statistik menunjukkan perlakuan teknik blanching almond dan lama perkecambahan kedelai berpengaruh nyata $(\alpha=0.05)$ terhadap kenaikan protein larut air namun tidak ada interaksi keduanya. Hal ini dikarenakan asam fitat merupakan senyawa yang larut dalam air dimana pada perlakuan water blanching asam fitat akan larut pada air perebusan. Sedangkan pada steam blanching media pelarutan asam fitat adalah uap air panas sehingga hanya sedikit melarutkan asam fitat (Mahmod, 2012). Pada perkecambahan terdapat proses perendaman biji dimana proses imbibisi air akan 
mengaktifkan enzim-enzim yang ada di dalam biji untuk proses metabolisme termasuk enzim fitase yang juga terdapat pada biji. Enzim fitase atau mio-inositol hesakisfosfat fosfohidrolase menghidrolisis asam fitat menjadi mio inositol dan fosfat organik dan kemudian mio-inositol dipecah lebih lanjut menjadi monofosfat. Hasil pemecahan asam fitat kemudian digunakan untuk pertumbuhan menjadi tanaman baru. Unsur yang digunakan adalah fosfor karena asam fitat merupakan sumber penyimpanan fosfor terbesar pada tanaman (Nagel, 2010).

\section{Tanin}

Pada Tabel 2 hasil analisis statistik menunjukkan perlakuan teknik blanching almond dan lama perkecambahan kedelai tidak berpengaruh nyata $(\alpha=0.05)$ terhadap penurunan kadar tanin produk. Hal ini dikarenakan asam fitat merupakan senyawa yang larut dalam air dimana pada perlakuan water blanching asam fitat akan larut pada air perebusan. Sedangkan pada steam blanching media pelarutan asam fitat adalah uap air panas sehingga hanya sedikit melarutkan asam fitat (Mahmod, 2012). Pada perlakuan pekecambahan terdapat pula perlakuan perendaman dimana proses imbibisi air ke biji akan menyebabkan enzim-enzim yang terdapat pada biji menjadi aktif untuk proses metabolisme termasuk enzim tannase (tannin acyl hydrolase). Enzim tersebut secara khusus memutuskan ikatan galoil pada tanin terhidrolisis untuk menghasilkan asam galat dan pliol. Selain itu tanase juga memiliki kemampuan mengkatalis reaksi hidrolisis tanin terkondensasi untuk menghasilkan senyawa flavonoid (Anwar, 2006).

\section{Perlakuan terbaik}

Penentuan perlakuan terbaik didasarkan pada kadar protein larut air tertinggi dengan kadar asam fitat dan tanin yang sudah memenuhi standar. Maksimal toleransi asam fitat yang di konsumsi adalah $800 \mathrm{mg} /$ hari (Ellis et al., 2001) sedangkan batas aman konsumsi tanin adalah $560 \mathrm{mg} / \mathrm{kg}$ berat badan/hari (Baskin dan Brewer, 2006). Kadar protein larut air tertinggi terdapat pada perlakuan steam blanching almond dan perkecambahan kedelai 36 jam dengan kadar protein larut sebesar $15.01 \%$ dengan kadar asam fitat $1.07 \mathrm{mg} / \mathrm{ml}$ dan kadar tanin $232.47 \mathrm{mg}$ ekuivalen asam tanat/100ml. Hasil analisis proximat perlakuan terbaik dapat dilihat pada Tabel 3.

Tabel 3. Rerata Proximat Perlakuan Terbaik Susu Almond Substitusi Sari Kecambah Kedelai

\begin{tabular}{lc}
\hline \multicolumn{1}{c}{ Parameter } & Hasil (\%) \\
\hline Kadar Air & $81.15 \pm 2.26$ \\
Kadar Protein & $15.01 \pm 0.48$ \\
Kadar Lemak & $1.99 \pm 0.17$ \\
Kadar Abu & $0.74 \pm 0.67$ \\
Karbohidrat (by difference) & 1.11 \\
\hline
\end{tabular}

Hasil yang disajikan pada Tabel 3 tersebut keseluruhan memenuhi standar SNI 013830-1995 tentang minuman berbasis kedelai dimana total padatan pada susu atau minuman kedelai minimal $11.5 \% \mathrm{~b} / \mathrm{b}$. Pada hasil analisis padatan total mencapai $18.85 \%$. Kadar protein susu almond substitusi sari kecambah kedelai mencapai $15.01 \%$ dimana peraturan SNI menjelaskan kadar protein pada susu kedelai minimal $2 \% \mathrm{~b} / \mathrm{b}$ atau dalam bentuk minuman minimal $1 \% \mathrm{~b} / \mathrm{b}$. Kadar lemak dan karbohidat hampir sama dengan susu almond pada umumnya yakni $1.04 \%$ dan $6.59 \%$ (USDA, 2016). Hasil tersebut juga memenuhi SNI dimana kadar lemak pada susu kedelai minimal $1 \% \mathrm{~b} / \mathrm{b}$ dan dalam bentuk minuman minimal $0.3 \%$.

\section{Klaim Sumber Protein}

Klaim kandungan zat gizi berupa minuman sumber protein wajib memenuhi sejumlah persyaratan yang ditetapkan dalam Peraturan Kepala Badan Pengawas Obat dan Makanan No. 13 Tahun 2016 yaitu memenuhi persyaratan asupan per saji tidak boleh lebih dari $18 \mathrm{~g}$ lemak total, $4 \mathrm{~g}$ lemak jenuh, $60 \mathrm{mg}$ kolesterol, $300 \mathrm{mg}$ natrium serta $10 \%$ ALG per $100 \mathrm{ml}$ (dalam bentuk cair) sebagai klaim sumber protein. Hasil analisis perlakuan terbaik 
(kandungan per takaran saji produk $250 \mathrm{ml}$ ) didapatkan kadar lemak sebesar $4.89 \mathrm{~g}$, natrium $21.93 \mathrm{mg}$, protein $15.01 \%$. Kolesterol dan lemak jenuh tidak dilakukan analisis karena keterbatasan alat, bahan dan materiil. Berdasarkan hasil tersebut dapat disimpulkan bahwa produk telah memenuhi persyaratan sebagai minuman sumber protein namun diperlukan analisis lebih lanjut untuk kolesterol dan lemak jenuh yang belum dilakukan.

\section{Informasi Nilai Gizi}

Perhitungan informasi nilai gizi mengacu paca ALG (Acuan Label Gizi) berdasarkan PKABPOM No.9. Pada informasi nilai gizi per takaran saji $(250 \mathrm{ml})$ produk dapat memenuhi kebutuhan energi $200 \mathrm{kkal}$ dengan energi dari lemak sebesar $40 \mathrm{kkal}$ lemak $8 \%$ AKG, protein $62 \%$ AKG, karbohidrat 1\% AKG, dan natrium 1\% AKG dengan persen AKG didasarkan pada kebutuhan energi $2000 \mathrm{kkal}$ dimana kebutuhan energi masing-masing individu mungkin lebih tinggi atau lebih rendah.

\section{SIMPULAN}

Perlakuan teknik blanching almond dan perkecambahan kedelai memberikan pengaruh nyata $(\alpha=0.05)$ terhadap kenaikan kadar protein larut air serta terdapat interaksi, juga berpengaruh nyata $(\alpha=0.05)$ pada penurunan kadar asam fitat namun tidak terdapat interaksi tidak pada tanin. Perlakuan terbaik didapatkan pada perlakuan steam blanching almond dan perkecambahan kedelai 36 jam dengan hasil kadar air $81.15 \%$, protein $15.01 \%$, lemak 1,99\%, karbohidrat by difference $1.11 \%$, abu $0.75 \%$, dan natrium 87.72 ppm. Hasil analisis yang didapat disimpulkan sementara telah memenuhi syarat klaim minuman sumber protein berdasarkan syarat minimum kandungan lemak jenuh, natrium, dan protein. Pada informasi nilai gizi per takaran saji $(250 \mathrm{ml})$ produk dapat memenuhi kebutuhan energi $200 \mathrm{kkal}$, lemak $8 \%$ AKG, protein $62 \%$ AKG, karbohidrat $1 \%$ AKG, dan natrium $1 \%$ AKG. Syarat kandungan lemak jenuh (minimum $4 \mathrm{~g}$ ) dan kolesterol (minimum $60 \mathrm{mg}$ ) sebagai pemenuhan syarat klaim minuman sumber protein belum dilaksanakan karena keterbatasan alat, bahan, serta materiil sehingga dibutuhkan penelitian lebih lanjut sebagai pemenuhan syarat klaim minuman sumber protein.

\section{DAFTAR PUSTAKA}

Anwar, YA.S. 2006. Produksi dan Karakterisasi Enzim Tanin Asil Hidrolase Dari Aspergillus niger. Disertasi Doktor. Sekolah Pascasarjana Institut Pertanian Bogor. Bogor.

AOAC. 1990. Official Method of Analysis. Association of Official Analysis Chemistry, Rockvile USA.

AOAC. 1995. Official Method of Analysis. Association of Official Analysis Chemistry, Rockvile USA.

AOAC. 2000. Official Method of Analysis. Association of Official Analysis Chemistry, Rockvile USA.

AOAC. 2005. Official Method of Analysis. Association of Official Analysis Chemistry, Rockvile USA.

Baskin, S.I., and Brewer, T.G. 2006. Cyanide Poisoning. Army Medical Research Institute of Chemical Defense. Marylane.

Davies N.T., and Reid. 1979. An Evaluation of The Phytate, Zinc, Copper, Iron and Manganese Contents of, and Zn Availability From, Soyabased Textured-VegetableProtein Meat-Substitues or Meat Extenders. Journal Nutrition. 41:3, 579-89.

Ellis R., Kelsay J.L., Reynolds R.D., Morris E.R., Moser P.B., and Frazier C.W. 2001. Phytate: Zinc and Phytate X Calcium: Zinc Millimolar Rations in Self-Selected Diets of American, Asian Indians, and Nepalese. Journal of the American Dietetic Association. 87:8, 1043-7.

Kumar, V, Sinha AK., Makkar HPS and Becker K. 2010. Dietary Roles of Phytate and Phytase in Human Nutrition: a Review. Journal of Food Chemistry 120: 945-959. 
Loewus, F. 2002. Biosynthesis of Phytate In Food Grains And Seeds: Food Phytates. CRC Press. Boca Raton.

Mahmod, M.H., Ferial M.A.S., El-kalyoubi M.H., and Gibriel A.Y. 2012. Effect of Legume Processing and Fermentation Treatments on Their Phytic Acid. Food Science Department. Cairo. Egypt.

Mardiyanto, T.C., dan Sri S. 2015. Studi Nilai Cerna Protein Susu Kecambah Kedelai Varietas Lokal secara In Vitro. Prosiding Seminar Nasional Masyarakat Biodiversitas Indonesia. Universitas Negeri Semarang. Semarang.

Nareswara AS. 2016. Studi Tentang Susu Almond Dan Kentang Sebagai Alternatif Minuman Fungsional Untuk Anak Autis. Skripsi. Universitas Diponegoro. Semarang.

Nagel, R. 2010. Living With Phytic Acid. http://www.westonaprice.org/health-topics/living-withphytic-acid/ Tanggal akses: 27/09/2016

Naibaho, M.N., Hudaida S., dan Hadi S. 2009. Studi Waktu Dan Metode Blanching Terhadap Sifat Fisikokimia Tepung Talas Belitung (Xanthosoma sagittifolium). Jurnal Teknologi Pertanian 4:2, 69-74.

Nielsen, A.O.D. 2016. Americans Are Nuts For Almond Milk. Dilihat 1 Mei 2017. <http://www.nielsen.com/us/en/insights/news/2016/americans-are-nuts-for-almondmilk.html. Tanggal akses: 01/05/2017.

Peraturan Kepala BPOM Republik Indonesia No. 9. 2016. Acuan Label Gizi. Berita Negara Republik Indonesia No. 792. Jakarta.

Peraturan Kepala BPOM Republik Indonesia No. 13. 2016. Pengawasan Klaim Pada Label dan Iklan Pangan Olahan. Berita Negara Republik Indonesia No 887. Jakarta.

Peraturan Kepala BPOM Republik Indonesia No. 9. 2015. Pengawasan Takaran Saji Pangan Olahan. Berita Negara Republik Indonesia No. 1055. Jakarta.

Potter, C. 2014. Almond Milk Sweetened with Dates (dairy free, refined sugar free). http://colorfuleatsnutrition.com/recipes/almond-milk-sweetened-with-dates. Tanggal akses: 27/09/2016.

Pramita, DS. 2008. Pengaruh Teknik Pemanasan Terhadap Kadar Asam Fitat dan Aktivitas Antioksidan Koro Benguk (Mucuna Pruriens), Koro Glinding (Phaseolus Lunatus), dan Koro Pedang (Canavalia Ensiformis). Skripsi. Universitas Sebelas Maret. Surakarta.

Purba, LS. 2012. Perbandingan Berat Kacang Kedelai Tergerminasi dan Biji Nangka dan Konsentrasi Ragi Pada Pembuatan Tempe. Skripsi. Universitas Sumatera Utara. Medan.

Purwati, N.A.D., Dian H. dan Amalia R. 2015. Es Krim Free Lactose Berbahan Dasar Sari Hanjeli sebagai Alternatif Pengganti Es Krim Susu bagi Penderita Lactose Intolerance. Jurnal Aplikasi Teknologi Pangan 4:1, 144-159.

Rusydi, M.M.R., dan Azrina, A. 2012. Effect of Germination On Total Phenolic, Tannin and Phytic Acid Contents in Soy Bean And Peanut. International Food Research Journal 19:2, 673-677.

SNI (Standar Nasional Indonesia). 1995. SNI 01-3830-1995: Susu Kedelai. http://sisni.bsn.go.id/index.php?/sni_main/sni/detail_sni/4246. Tanggal akses: 01/03/2017.

Suhendra L. 2005. Studi Perubahan Protein Terlarut Selama Perkecambahan Biji Wijen (Sesamun Indicum L.) Menggunakan Pendekatan Respon Surface Methodology. Skripsi. Universitas Udayana. Bali

Tan, J. 2011. Healthy Nuts Go Nuts. http://www.med.umich.edu/pfans/docs/tip2011/healthynuts-0211.pdf. Tanggal akses: 15/092016.

USDA (United States Department of Agriculture) - Natural Resources Concervating Service. 2016. Classification for Kingdom Plantae Down to Genus Prunus L. https://plants.usda.gov/java/ClassificationServlet?source=display\&classid=PRUNU. Tanggal akses: 15/09/2016.

USDA (United States Department of Agriculture). 2016. USDA Branded Food Products Database for Almond Milk. https://ndb.nal.usda.gov/ndb/ search/list. Tanggal akses: 15/09/2016. 
USDA (United States Department of Agriculture). 2016. USDA Branded Food Products Database for Dry Almond Nuts. https://ndb.nal.usda.gov/ndb/search/list. Tanggal akses: 15/09/2016.

USDA (United States Department of Agriculture). 2016. USDA Branded Food Products Database for Dry Soya Bean. https://ndb.nal.usda.gov/ndb/search/list. Tanggal akses: $15 / 09 / 2016$

Victoria, J. E. 2008. Daniel's Lifestyle Fasting Cook Book. Xulon Press. Maitland.

Yuwono, SS, Kartika KH. dan Wulan S.N. 2003. Karakterisasi Fisik, Kimia dan Fraksi Protein 7S Dan 11S Sepuluh Varietas Kedelai Produksi Indonesia. Jurnal Teknologi Pertanian $4: 1,84-90$. 